\title{
THE RESIDENT SURGEON PHACOEMULSIFICATION LEARNING CURVE AT CLINICAL DEPARTMENT OF OPHTHALMOLOGY, SESTRE MILOSRDNICE UNIVERSITY HOSPITAL CENTER
}

\author{
Valentina Lacmanović Lončar ${ }^{1}$, Rašeljka Tadić ${ }^{1}$, Lana Dujmović ${ }^{1}$, Lana Knežević \\ Ana Koluder ${ }^{2}$, Marta Vidović ${ }^{3}$, Iva Krolo ${ }^{1}$, Željko Kaurićc ${ }^{4}$, Vanda Gašpar Mitrečić ${ }^{5}$, \\ Ivanka Petric Vicković ${ }^{1}$, Renata Iveković ${ }^{1}$ and Zoran Vatavuk ${ }^{1}$
}

${ }^{1}$ Clinical Department of Ophthalmology and Optometry, Sestre milosrdnice University Hospital Center, Zagreb; ${ }^{2}$ Dr Tomislav Bardek General Hospital, Koprivnica; ${ }^{3}$ Nova Gradiška General Hospital, Nova Gradiška;

${ }^{4}$ Dr Ivo Pedišić General Hospital, Sisak; ${ }^{5}$ Karlovac General Hospital, Karlovac, Croatia

\begin{abstract}
SUMMARY - The aim of the study was to analyze the resident learning process of phacoemulsification cataract surgery and to assess the resident phacoemulsification learning curve. This prospective study comprised 86 consecutive cases of phacoemulsification performed using standard technique by eight residents over a one-year period at Clinical Department of Ophthalmology, Sestre milosrdnice University Hospital Center in Zagreb. Operative data on each case included resident and attending surgeon, date of operation, step-by-step success questionnaire, and intraoperative complications. Postoperative data included visual acuity at one-month postoperative visit and postoperative complications. Eighty-six operations were performed under the supervision of attending surgeon. The mean best-corrected visual acuity improved from $0.47 \pm 0.25$ to $0.8 \pm 0.25$ postoperatively. Intraoperative complications occurred in $13(15.12 \%)$ cases and continued to decrease throughout residency training. The mean number of individually performed steps per operation increased throughout residency (from 7.6 to 9.0 ). There was one early postoperative complication, endophthalmitis, which was successfully treated, and no other postoperative complications occurred. Resident surgical competency can be improved by maximizing the number of cataract procedures since the complication rates and the number of individually performed steps improved continuously with increasing surgical experience.
\end{abstract}

Key words: Cataract surgery; Resident learning curve; Phacoemulsification; Posterior capsular tear; Intraoperative complications

\section{Introduction}

Phacoemulsification is the gold standard for cataract extraction all over the world, as well as the most common surgical procedure. Still, it is one of the most challenging procedures to master during residency. As it has become the procedure of choice for most cata-

Correspondence to: Rašeljka Tadić, MD, Clinical Department of Ophthalmology and Optometry, Sestre milosrdnice University Hospital Center, Vinogradska c. 29, HR-10000 Zagreb, Croatia E-mail: raseljkas@gmail.com

Received January 27, 2016, accepted April 25, 2016 ract surgeries, learning phacoemulsification technique is an important part of resident education. The Accreditation Council for Graduate Medical Education requires 86 primary surgeon cases to be completed by the end of residency in the United States ${ }^{1}$, while the Royal College of Ophthalmologists requires 50 phacoemulsification cases completed by residents over the first 2 years and 350 after 7 years of training ${ }^{2}$. Unfortunately, even though ophthalmology residents in foreign countries spend a large proportion of their surgical training learning cataract surgery ${ }^{3}$, in our country it was not common practice ${ }^{4}$. As many previous studies 
showed that complication rates and outcomes of cataract surgery performed by residents were acceptable ${ }^{5-12}$, it was decided to start first resident phacoemulsification-learning program at the Clinical Department of Ophthalmology, Sestre milosrdnice University Hospital Center. The purpose of this pilot study was to analyze the resident learning process of phacoemulsification cataract surgery at the Clinical Department of Ophthalmology, Sestre milosrdnice University Hospital Center, and to assess the resident phacoemulsification learning curve in order to implement cataract surgery training into the residency program in the future.

\section{Material and Methods}

This prospective study comprised 86 consecutive cases of phacoemulsification performed by eight residents over a one-year period at Clinical Department of Ophthalmology, Sestre milosrdnice University Hospital Center in Zagreb. During the study period, resident surgeons at the second, third and last year of residency performed all cases after approval by attending ophthalmologists. Four of eight residents had prior extracapsular cataract extraction experience and others had previous wet lab experience. Preoperatively collected data included patient age, sex, operated eye, best corrected visual acuity (BCVA) and type of cataract. Patients with other ocular comorbidities were excluded. The senior cataract surgeon was present throughout the procedures. In all cases, the residents used standard technique under topical or local anesthesia. After clear cornea incision (knife $2.4 \mathrm{~mm}$ ) and paracentesis, continuous curvilinear capsulorhexis was performed using forceps. After hydrodissection and hydrodelination, the lens was phacoemulsified, usually with 'dived and conquer' technique using the Alcon Infinity Vision system phacomachine. When possible, three-piece foldable MA60AC Acrysoft intraocular lens (Alcon, Fort Worth, USA) was inserted in the posterior chamber, followed by aspiration of the remaining viscoelastic. After instillation of antibiotic (Ketocef, Pliva Hrvatska, Zagreb, Croatia) in the anterior chamber, corneal incision and paracentesis were hydrated. When needed, clear corneal incision was sutured using 10-0 suture. At the end of surgery, corticosteroid subconjunctival injection was administered. At the end of surgery, the trainees completed a questionnaire defining for each of 10 steps whether they succeeded to perform it alone or with assistance of the senior surgeon. Operative data obtained on each case included resident and attending surgeon, date of operation, stepby-step success questionnaire, intraoperative complications, and resident case number representing actual experience of the individual resident. Postoperative data collected included visual acuity at one-month postoperative visit and postoperative complications. At the end of the study, all residents completed a questionnaire rating the degree of difficulty of 10 individu-

\section{SUBJECTIVE DIFFICULTY OF EACH STEP IN PHACOEMULSIFICATION SURGERY}

NAME:

\begin{tabular}{|c|c|c|c|c|c|c|c|}
\hline STEP & \multicolumn{7}{|c|}{ SCORE } \\
\hline CORNEAL INCISION & very easy & 1 & 2 & 3 & 4 & 5 & very difficult \\
\hline PARACENTESIS & very easy & 1 & 2 & 3 & 4 & 5 & very difficult \\
\hline VISCOELASTIC INJECTION & very easy & 1 & 2 & 3 & 4 & 5 & very difficult \\
\hline CAPSULORHEXIS & very easy & 1 & 2 & 3 & 4 & 5 & very difficult \\
\hline HYDRODISSECTION & very easy & 1 & 2 & 3 & 4 & 5 & very difficult \\
\hline PHACOEMULSIFICATION & very easy & 1 & 2 & 3 & 4 & 5 & very difficult \\
\hline $\mathrm{I} / \mathrm{A}$ & very easy & 1 & 2 & 3 & 4 & 5 & very difficult \\
\hline IOL INSERTION & very easy & 1 & 2 & 3 & 4 & 5 & very difficult \\
\hline VISCOELASTIC REMOVAL & very easy & 1 & 2 & 3 & 4 & 5 & very difficult \\
\hline HYDRATION & very easy & 1 & 2 & 3 & 4 & 5 & very difficult \\
\hline DEXA INJECTION & very easy & 1 & 2 & 3 & 4 & 5 & very difficult \\
\hline
\end{tabular}

Fig. 1. The questionnaire to assess subjective difficulty in performing each step. 
al phacoemulsification stages on a 5-point scale from 1 (very easy) to 5 (very difficult) (Fig. 1). Statistical analysis was performed using Microsoft Excel.

\section{Results}

Eight residents performed 86 operations under the guidance of three attending surgeons with relatively even case distribution among residents (mean number of cases: $10.75 \pm 2.56) ; 73(84.88 \%)$ procedures were successfully performed without complications, whereas some complications occurred in 13 (15.12\%) cases. The mean patient age at the time of surgery was $68 \pm 7.56$ years. None of the procedures had to be con- verted to extracapsular cataract extraction (ECCE). The mean BCVA improved from $0.47 \pm 0.25$ to $0.8 \pm 0.25$ postoperatively.

In order to establish learning curve for each resident, we evaluated the number of successfully individually performed steps of operation for each resident case number during training period and identified those steps that most commonly needed assistance by senior surgeon. The mean number of individually performed steps per operation was 7.6 at beginning and 9.3 at the end of the study (Fig. 2). Figure 3 shows the percentage of success in performing each step in all operations.

Steps that most commonly needed assistance were capsulorhexis (44.19\%, mean 19), phacoemulsification

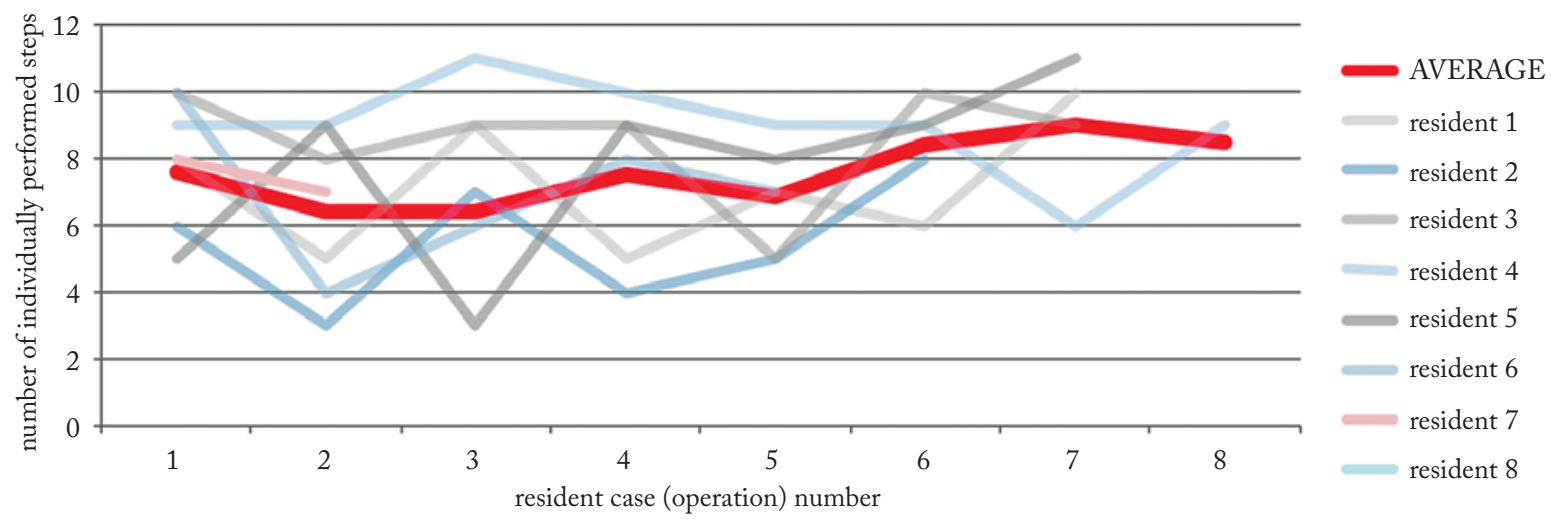

Fig. 2. The resident learning curve: number of individually performed steps per resident case number.

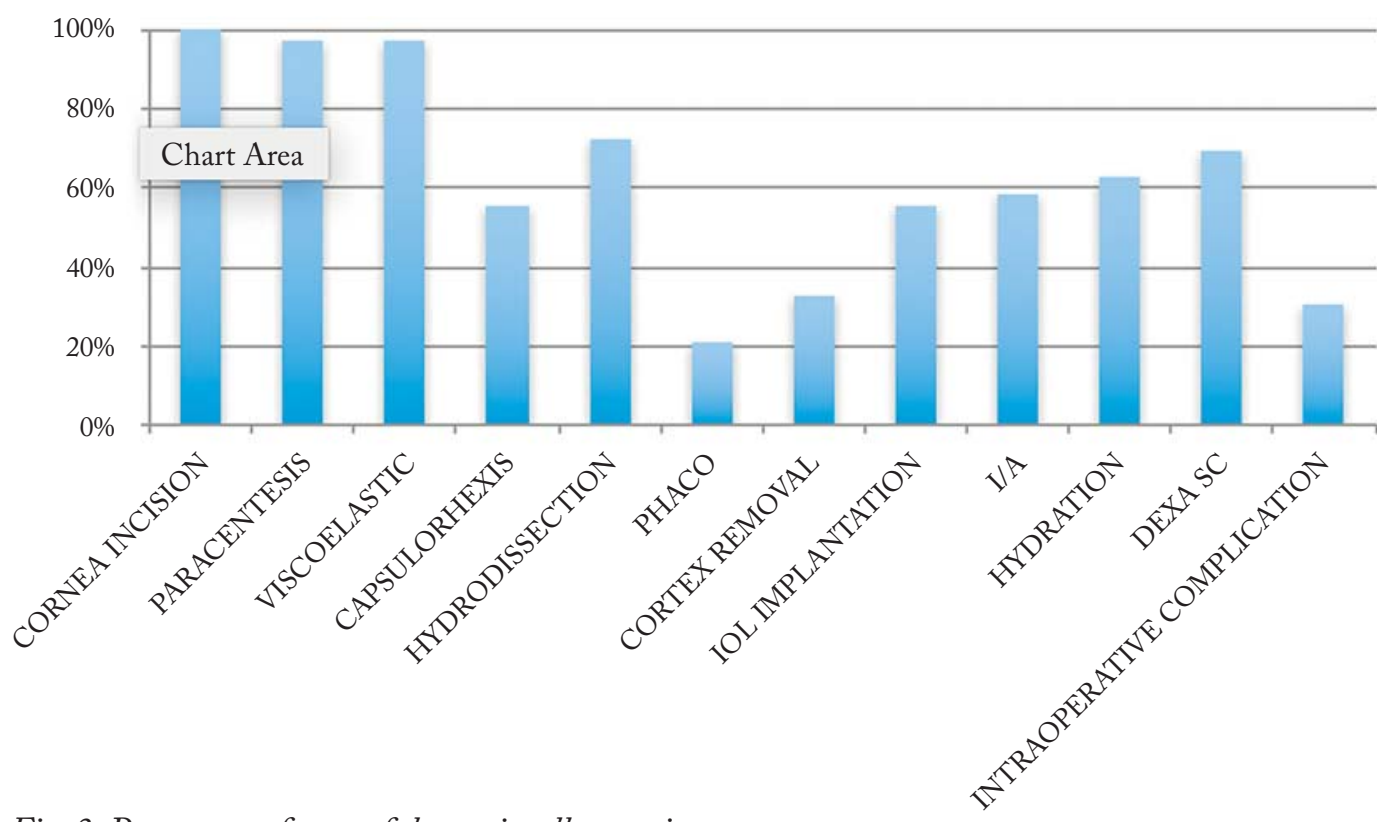

Fig. 3. Percentage of successful steps in all operations. 


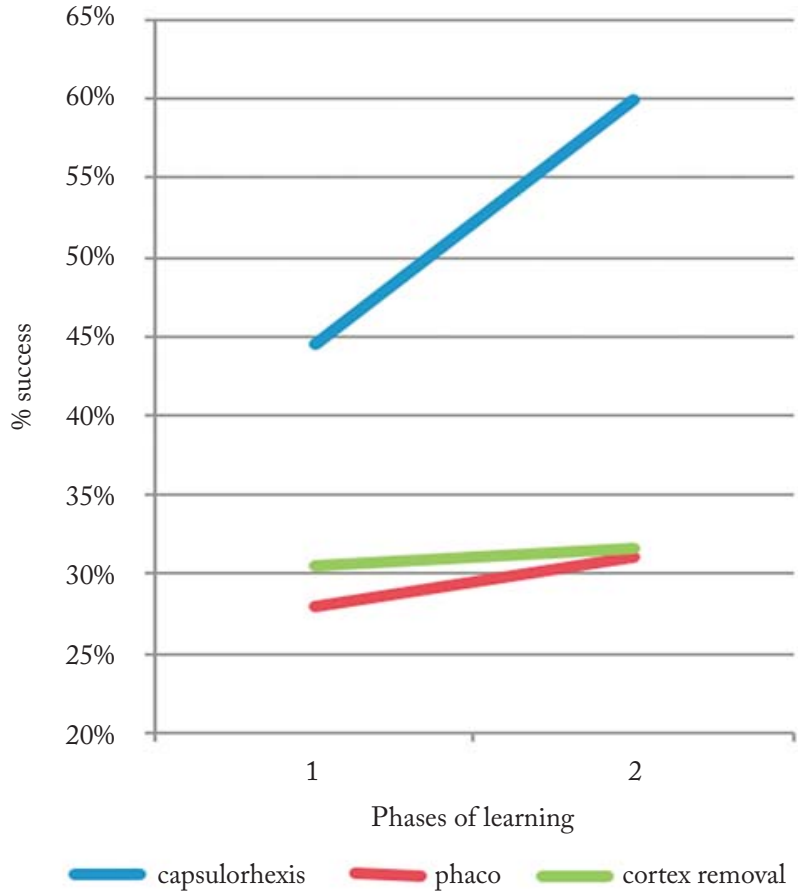

Fig. 4. Improvement in performing most difficult steps by increasing resident experience.

(19.78\%, mean 34) and cortex removal (37.00\%, mean 29). When comparing success in performing these steps at the beginning with cases at the end of the study, improvement in performance was recorded throughout the period of residency training (Fig. 4).

Intraoperative complications occurred in $13(15.12 \%)$ cases and included posterior capsular tear in 13 cases and one case of nucleus drop. Posterior capsular tear occurred in 8 cases during phacoemulsification and in 5 cases during cortex aspiration. Comparison of the resident case number recorded at the beginning (first five operations) and later in the period of training showed a decrease in the rate of intraoperative complications (8.14\% vs. 6.98\%) (Fig. 5). The rate of complications continued to decrease throughout residency training. The mean postoperative follow up period was 6 months. There was one early postoperative complication, endophthalmitis, which was successfully treated, and no other postoperative complications such as cystoid macular edema or keratopathy were observed.

According to resident subjective judgment, the most difficult stages were phacoemulsification and capsulorhexis with the highest scores $(4.8 \pm 0.4$ and $3.6 \pm 0.5)$, followed by cortex aspiration (3.33 \pm 1.4$)$ with completion rates of $20.93 \%, 55.81 \%$ and $32.56 \%$, respectively.

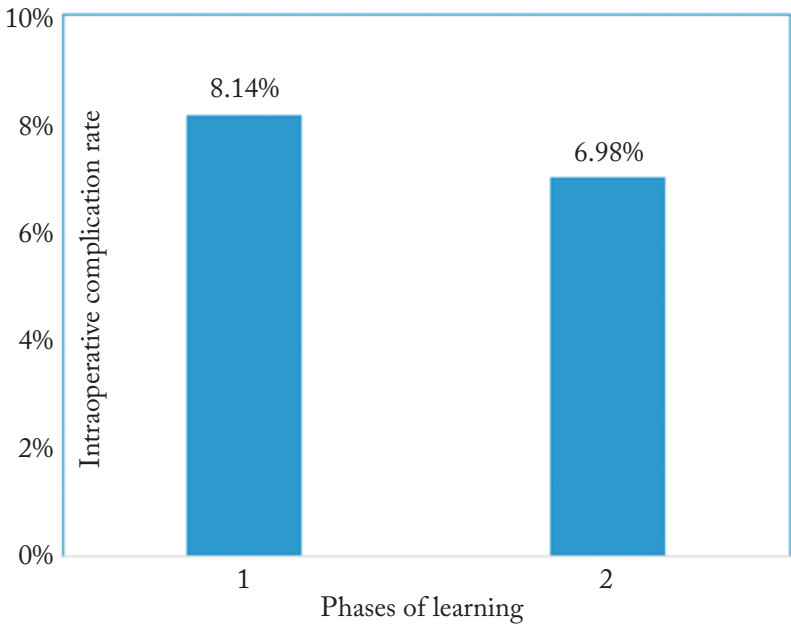

Fig. 5. Decrease in the intraoperative complication rate.

The last two steps of subconjunctival corticosteroid injection and hydratization of incisions, and the first two steps of corneal incision and paracentesis were easiest to perform, yielding a nearly $100 \%$ completion rate, while hydrodissection, irrigation/aspiration and intraocular lens insertion had difficulty rates of $3.3 \pm 1.2$, $2.0 \pm 0.89$ and $3.0 \pm 1.41$, with completion rates of $72.09 \%, 58.14 \%$ and $55.81 \%$, respectively (Fig. 6).

\section{Discussion}

In our study, most patients achieved very good visual acuity $(0.8 \pm 0.25)$ after resident operation, which is consistent to other literature reports ${ }^{13,14}$. This can be explained by good case selection and excluding patients with other preexisting ocular comorbidities. Careful patient selection appears to be very important for overall success, especially in resident early cases ${ }^{9,11,15}$.

According to our results, phacoemulsification, capsulorhexis and cortex aspiration are steps that most commonly require assistance of senior surgeon (a1though increasing success is recorded with the increasing number of operations, i.e. resident experience). Our data suggest that the learning curve for capsulorhexis is faster than that for cortex aspiration and phacoemulsification. For mastering these steps, residents require more successive cases over time, as shown by Robin et al. ${ }^{7}$. Baxter et al. report that high-frequency intensive surgical training leads to safe and efficient mastering of phacoemulsification steps with a low rate of intraoperative complications (0.66\%) and high completion rate after first 6 months ${ }^{12}$. 


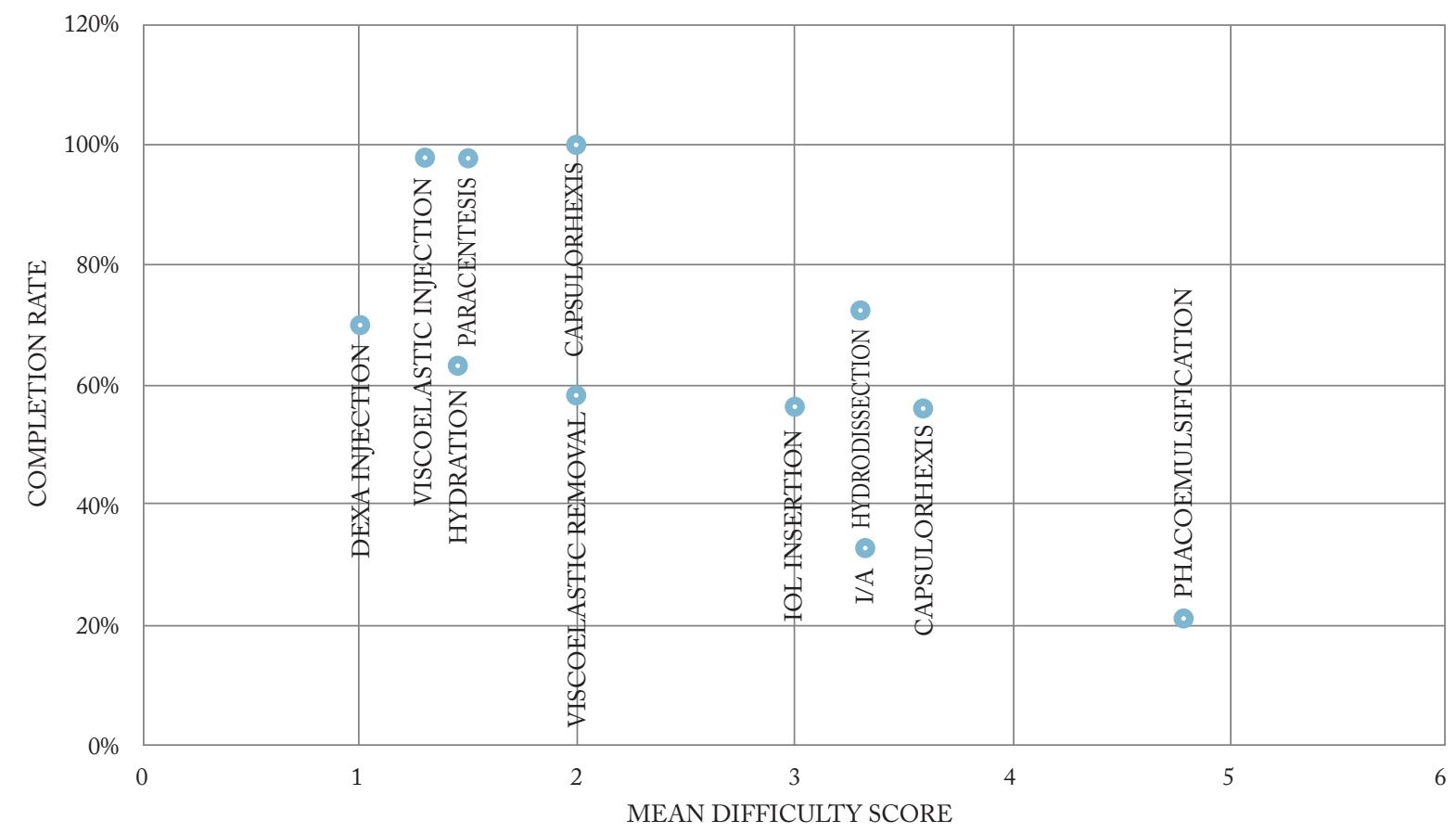

Fig. 6. Completion rate and mean difficulty score in each step.

In our study, the overall intraoperative complication rate $(15.12 \%)$ was in the upper normal range reported elsewhere $(1.8 \% \text { to } 15 \%)^{5-12}$. This could be explained by the fact that half of the trainees (4/8) were at the very beginning of the operating learning curve, having only wet lab experience. Although some authors report that prior experience in standard ECCE is required for safe phacoemulsification technique learning, we agree with Quillen et al., Rutar et al. and Briszi et al., who report the rate of intraoperative complications to be comparable for third-year residents with and without previous ECCE experience ${ }^{9-11}$. Additionally, a relatively low mean number of operations per resident was the greatest limitation of our study since Randleman et al. showed the rate of posterior capsular tear to decrease beyond the first 200 cases and the rate of vitreous loss after the first 80 cases $^{13}$. Our study confirmed the rate of intraoperative complications to decrease during learning process with the increasing number of operations, as previously reported $^{9,10,13,14,16}$. Based on the report by the Residency Review Committee of Accreditation Council for Graduate Medical Education ${ }^{1}$, according to which the minimum number of cataract procedures performed by resident as primary surgeon should be 86 , we intend to continue our training program in order to improve our resident skills and competency. Concerning subjective difficulty in each step of the operation, residents found phacoemulsification and capsulorhexis to be the most difficult steps in the learning curve. These results are similar to those reported by Dooley and O'Brien ${ }^{14}$. Lower completion rates for the last steps, which were marked as easy in our study, could be explained by the fact that in cases where previous step needed assistance of senior surgeon, he usually would finish the operation. Our study was designed for residents to start learning the procedure from the beginning and senior surgeon would intervene in the stage where resident would have problems, often finishing the operation. Comparing subjective judgment with objective completion rate of individual steps, our study indicated that learning process should be started with easiest steps, so that the need for senior surgeon to take over early in the course of surgery would be reduced to minimum. Such a step-by-step training program has already been reported by Yulan et al. as a safe and effective way for residents to achieve independent phacoemulsification cataract surgery skills ${ }^{17}$. The low overall completion rate in our study (4.65\%) supports the step-by-step training program to be recommended in the learning process. As a result of our study, we plan to improve the quality of the resident training program 
at our Department by maximizing the number of cataract procedures performed by residents and implementing the step-by-step training model.

\section{References}

1. Accreditation Council for Graduate Medical Education [Internet]. Ophthalmology resident operative minimum requirements. Available from: http:/www.acgme.org/acWebsite/RRC _240/240_MinimumsOPerativeTable.pdf.

2. Royal College of Ophthalmologists Training Committee [Internet]. Guide for Basic Specialist Training in Ophthalmology. Available from: http://www.rcophth.ac.uk./edu-train-docs/ GuifetoBST.pdf.

3. Rowden A, Krishna R. Resident cataract surgical training in United States residency programs. J Cataract Refract Surg. 2002;28(12):2202-5.

4. Vatavuk Z, Vrabec R, Benčić G, Čima A, Mandić K, Mandić Z. Analysis of current ophthalmology residency curriculum. Acta Clin Croat. 2007;46(Suppl 1):45-50.

5. Prasad S. Phacoemulsification learning curve: experience of two junior trainee ophthalmologists. J Cataract Refract Surg. 1998;24(1):73-7.

6. Hennig A, Schroeder B, Kumar. Learning phacoemulsification. Results of different teaching methods. Indian J Ophthalmol. 2004;52(3):233-4.

7. Robin AL, Smith SD, Natchiar G, Ramakrishnan R, Srinivasan M, Raheem R, Hecht W. The initial complication rate of phacoemulsification in India. Invest Ophthalmol Vis Sci. 1997; 38(11):2331-7.

8. Thomas R, Naveen S, Jacob A, Braganza A. Visual outcome and complications of residents learning phacoemulsification. Indian J Ophthalmol. 1997;45(4):215-9.
9. Rutar T, Porco TC, Naseri A. Risk factors for intraoperative complications in resident-performed phacoemulsification surgery. Ophthalmology. 2009;116(3):431-6. doi: 10.1016/j.ophtha.2008.10.028. Epub 2009 Jan 22.

10. Briszi A, Prahs P, Hillenkamp J, Helbig H, Herrmann W. Complication rate and risk factors for intraoperative complications in resident-performed phacoemulsification surgery. Graefes Arch Clin Exp Ophthalmol. 2012;250(9):1315-20.

11. Quillen DA, Phipps SJ. Visual outcomes and incidence of vitreous loss for residents performing phacoemulsification without prior planned extracapsular cataract extraction experience. Am J Ophthalmol. 2003;135(5):732-3.

12. Baxter JM, Lee R, Sharp JA, Foss AJ; Intensive Cataract Training Study Group. Intensive cataract training: a novel approach. Eye (Lond). 2013;27(6):742-6.

13. Randleman JB, Wolfe JD, Woodward M, Lynn MJ, Cherwek $\mathrm{DH}$, Srivastava. The resident surgeon phacoemulsification learning curve. Arch Ophthalmol. 2007;125(9):1215-9.

14. Dooley IJ, O'Brien PD. Subjective difficulty of each stage of phacoemulsification cataract surgery performed by basic surgical trainees. Cataract Refract Surg. 2006;32(4):604-8.

15. Blomquist PH, Morales ME, Tong L, Ahn C. Risk factors for vitreous complications in resident-performed phacoemulsification surgery. J Cataract Refract Surg. 2012;38(2):208-14.

16. Tarbet KJ, Mamalis N, Theurer J, Jones BD, Olson RJ. Complications and results of phacoemulsification performed by residents. J Cataract Refract Surg. 1995;21(6):661-5.

17. Yulan W, Yaohua S, Jinhua T, Min W. Step-by-step phacoemulsification training program for ophthalmology residents. Indian J Ophthalmol. 2013;61(11):659-62.

Sažetak

\section{KRIVULJA UČENJA OPERACIJE MRENE METODOM FAKOEMULZIFIKACIJE SPECIJALIZANATA NA KLINICI ZA OFTALMOLOGIJU KLINIČKOG BOLNIČKOG CENTRA SESTRE MILOSRDNICE}

\section{Lacmanović Lončar, R. Tadić, L. Dujmović, L. Knežević, A. Koluder, M. Vidović, I. Krolo, Ž. Kaurić, V. Gašpar Mitrečic, I. Petric Vicković, R. Iveković i Z. Vatavuk}

Cilj ove studije bio je prikazati proces i krivulju učenja specijalizanata oftalmologije i optometrije u operaciji katarakte metodom fakoemulzifikacije. U ovom prospektivnom istraživanju izvedeno je 86 uzastopnih operacija katarakte metodom fakoemulzifikacije koju su u razdoblju od jedne godine na Klinici za oftalmologiju KBC "Sestre milosrdnice" učili specijalizanti oftalmologije uz nadzor iskusnih operatera. Prikupljeni operativni podatci uključili su specijalizanta operatera, mentora, datum operacije, upitnik uspješnosti po koracima operacije i intraoperacijske komplikacije. Poslijeoperacijski se pratila najbolje postignuta korigirana vidna oštrina operiranih nakon mjesec dana te razvoj poslijeoperacijskih komplikacija. Ukupno je učinjeno 86 operacija uz stalni nadzor iskusnijih operatera. Najbolje korigirana vidna oštrina operiranih poboljšala se sa srednje vrijednosti od $0,47 \pm 0,25$ na $0,8 \pm 0,25$ poslijeoperacijski. Intraoperacijske komplikacije su nastupile u $13(15,12 \%)$ operacija, ali se njihova učestalost tijekom vremena u procesu učenja smanjila. Prosječan broj samostalno učinjenih koraka po pojedinoj operaciji za svakog specijalizanta se povećao tijekom procesa učenja (prosječno od 7,6 do 9,0). Poslijeoperacijski se samo u jednog bolesnika razvio endoftalmitis, dok druge poslijeoperacijske komplikacije nisu zabilježene. Kirurške vještine specijalizanata se mogu poboljšati povećanjem broja i učestalosti učinjenih operacija tijekom vremena, jer učestalost intraoperacijskih komplikacija opada, a uspješnost svladavanja pojedinih koraka operacije raste s povećanjem kirurškog iskustva.

Ključne riječi: Operacija mrene; Krivulja učenja; Fakoemulzifikacija; Ruptura stražnje kapsule; Intraoperacijske komplikacije 